\title{
Pengaruh Keluhan Kesehatan terhadap Indeks Pembangunan Manusia Di Provinsi Jawa Timur
}

\author{
Nur Isnaeni Novitasari", Suharno, Arintoko \\ Fakultas Ekonomi dan Bisnis, Universitas Jenderal Soedirman, Purwokerto \\ *Correspondence email: nurisnaenin104@gmail.com
}

\begin{abstract}
Abstrak. Investasi pada sumber daya manusia sama dengan meningkatkan kualitas pembangunan manusia. Keberhasilan pembangunan nasional dapat dilihat dari aspek kesehatan dalam pengukuran Indeks Pembangunan Manusia. Penelitian ini menganalisis pengaruh keluhan kesehatan, pengangguran, kemiskinan dan pengeluaran pemerintah terhadap Indeks Pembangunan Manusia di Provinsi Jawa Timur 2015-2018. Metode penelitian menggunakan regresi linier berganda dengan pendekatan data panel. Hasil penelitian menunjukkan bahwa keluhan kesehatan, pengangguran dan kemiskinan berpengaruh negatif dan signifikan terhadap indeks pembangunan manusia di Provinsi Jawa Timur. Sementara itu, pengeluaran pemerintah berpengaruh positif dan signifikan terhadap indeks pembangunan manusia di Provinsi Jawa Timur. Temuan ini mengimplikasikan 1) perlunya peningkatan infrastruktur kesehatan dan pengeluaran pemerintah di bidang kesehatan, 2) perlunya peningkatan kesempatan kerja agar kemiskinan dan pengangguran berkurang.
\end{abstract}

Kata Kunci: Indeks Pembangunan Manusia; Keluhan Kesehatan; Pengangguran; Kemiskinan; Pengeluaran Pemerintah

\begin{abstract}
The Investments in human capital lead towards the quality improvement of human development. The success of national development can be seen from the health aspect in the form of measurement indicator of the Human Development Index. This research analyzes the effect of health complaints, unemployment, poverty and government expenditure on the Human Development Index in East Java Province 2015-2018. This research method uses multiple linear regression with a panel data approach. The results showed that health complaints, unemployment and poverty have a negative and significant effect on the Human Development Index in East Java Province. Meanwhile, government expenditure has a positive and significant effect on the Human Development Index in East Java Province. These findings imply 1) the necessity to improve health infrastructure and government expenditure especially in the health sector, 2) the necessity to increase employment opportunities for reducing poverty and unemployment.
\end{abstract}

Keywords: Human Development Index; Health Complaint; Unemployment; Poverty; Government Expenditure

\section{PENDAHULUAN}

Kesehatan merupakan salah satu bentuk modal manusia (human capital). Setiap individu menginginkan tubuh yang sehat, karena ketika tubuh memiliki kondisi kesehatan yang baik akan membentuk kehidupan menjadi lebih sejahtera (Bleakley, 2010). Modal manusia baik pada sektor pendidikan maupun kesehatan berdampak positif terhadap pertumbuhan ekonomi. Menurut Hendarmin \& Kartika (2019) investasi dalam modal manusia seperti pendidikan dan kesehatan adalah kunci meningkatkan kualitas pembangunan manusia yang berimplikasi terhadap peningkatan ekonomi suatu negara.

Berdasarkan data Badan Pusat Statistik (BPS) tahun 2018 jumlah penduduk Indonesia mencapai 265 juta jiwa yang tersebar di 34 provinsi. Pemerintah dalam hal ini memiliki peran penting untuk lebih memprioritaskan pembangunan kualitas sumber daya manusia sebagai kunci pembangunan nasional Indonesia kedepan. Menurut Elistia \& Syahzuni (2018) tingkat perkembangan manusia suatu negara dapat terlihat dari nilai Indeks Pembangunan Manusia (IPM). Indikator tersebut pertama kali diperkenalkan oleh United Nation Development Programme (UNDP) pada tahun 1990. Menurut United Nation Development Programme
(UNDP), Indeks Pembangunan Manusia merupakan salah satu indikator yang digunakan untuk mengukur tingkat keberhasilan pembangunan kualitas manusia di suatu negara atau regional pada kurun waktu tertentu.

Indeks Pembangunan Manusia (IPM) merepresentasikan tiga dimensi yaitu pada bidang kesehatan, pengetahuan dan standar hidup yang layak. Dimensi kesehatan dinilai dari angka harapan hidup. Dimensi pendidikan diukur dari rata-rata (tahun) sekolah untuk orang dewasa 25 tahun dan lebih. Dimensi standar hidup diukur dengan pendapatan nasional bruto perkapita (Arisman, 2018). Di Indonesia, Badan Pusat Statistik (BPS) juga menyatakan IPM terdiri dari tiga hal yang mendasarinya yaitu: (1) Umur panjang dan hidup sehat; (2) Pengetahuan; dan (3) Standar hidup layak. Penyajian data Indeks Pembangunan Manusia (IPM) pada Badan Pusat Statistik (BPS) tercatat bentuk periodik setiap tahun pada tingkat nasional, provinsi dan kabupaten/kota. Penyajian IPM dalam bentuk periodik suatu daerah memungkinkan setiap provinsi dan kabupaten/kota dapat mengetahui peta pembangunan manusia di daerahnya, baik pencapaian, kecepatan, posisi maupun disparitas daerah.

Provinsi Jawa Timur pada tahun 2018 memiliki jumlah penduduk sebanyak 39,5 juta jiwa atau $14,91 \%$ 
dari total populasi yang ada di Indonesia (BPS, 2019). Berdasarkan jumlah populasi penduduk, maka pertumbuhan Indeks Pembangunan Manusia (IPM) yang ada di Provinsi Jawa Timur memiliki kontribusi tinggi terhadap hasil Indeks Pembangunan Manusia yang ada di Indonesia (Hartanto et al., 2019). Pada Gambar 1 menunjukkan perbandingan rata-rata Indeks Pembangunan Manusia (IPM) disetiap provinsi di Pulau Jawa dan nasional pada tahun 2015-2018. Gambar tersebut memperlihatkan bahwa Provinsi Jawa Timur menjadi provinsi yang memiliki IPM sebesar 69,93 yang artinya terendah dibandingkan dengan provinsi lain yang ada di Pulau Jawa.

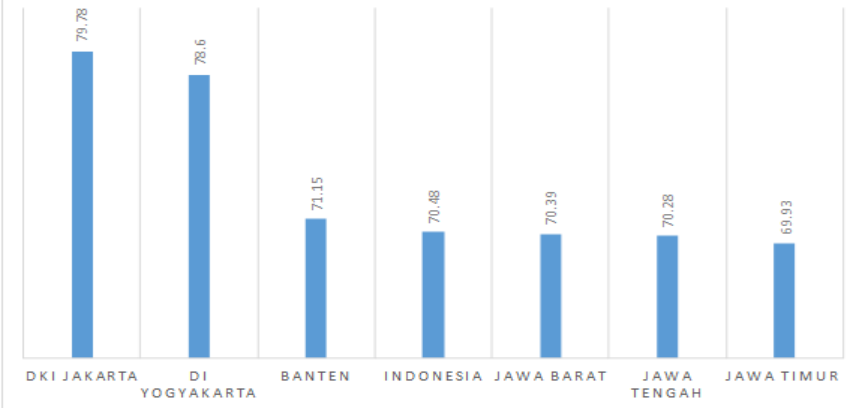

Gambar 1. Perbandingan Rata-Rata IPM Per Provinsi di Pulau Jawa dan Indonesia Periode 2015-2018

Sumber: Badan Pusat Statistik, 2019 (Data Diolah)

Menurut Hartanto et al. (2019) kategori Indeks Pembangunan Manusia yaitu terdiri dari: (1) Sangat tinggi (IPM $\geq 80$ ); (2) Tinggi ( $70 \leq$ IPM $<80$ ); (3) Sedang $(60 \leq$ IPM $<70)$; dan Rendah IPM $<60$. Mengacu pada angka tersebut, maka Provinsi Jawa Timur masih berada pada tingkat Indeks Pembangunan Manusia sedang dan tertinggal 0,55 dari rata-rata nasional. Indeks Pembangunan Manusia yang rendah dapat mengindikasikan kondisi kesehatan dalam suatu wilayah yang kurang baik. Menurut Serna et al. (2019) yang membahas mengenai hubungan antara Indeks Pembangunan Manusia dan komponennya dengan penyakit kanker mulut di Amerika Latin menyebutkan bahwa Haiti sebagai negara dengan kasus infeksi paling banyak memiliki Indeks Pembangunan Manusia terendah diantara negara lainnya.

Beberapa penelitian terkait Indeks Pembangunan Manusia (IPM) menghasilkan berbagai macam temuan. Pada penelitian Sofilda et al. (2015) menghasilkan: (1) Daerah yang memiliki IPM dibawah rata-rata IPM nasional dipengaruhi variabel rata-rata belanja perkapita, jumlah penduduk, tingkat pengangguran, alokasi anggaran pendidikan dan kesehatan; (2) Daerah yang memiliki IPM di atas rata-rata IPM nasional dipengaruhi oleh PDRB atas dasar harga konstan, belanja rata-rata per kapita, beban tanggungan, tingkat pengangguran dan anggaran pendidikan. Selain itu, penelitian Yuliani \& Saragih (2014) mengemukakan bahwa pengangguran memiliki pengaruh negatif terhadap IPM, sedangkan pertumbuhan ekonomi beserta pengeluaran pemerintah berpengaruh positif terhadap IPM di Kabupaten/Kota di Provinsi Jawa Tengah. Menambahkan Mirza (2011) terdapat pengaruh yang negatif dari kemiskinan terhadap IPM dan pengaruh yang positif dari pertumbuhan ekonomi serta belanja modal terhadap IPM di Provinsi Jawa Tengah. Berbeda dengan Arisman (2018) yang menemukan bahwa pengaruh terhadap IPM hanya berasal dari jumlah penduduk dan pertumbuhan per kapita, sedangkan tingkat pengangguran dan inflasi tidak mempengaruhi IPM di negara-negara anggota ASEAN.

Pada hakekatnya pembangunan manusia atau peningkatan kualitas sumber daya manusia menjadi hal yang sangat penting untuk menentukan strategi kebijakan pembangunan nasional. Penekanan terhadap pentingnya peningkatan sumber daya manusia dalam pembangunan menjadi suatu kebutuhan karena kualitas manusia di suatu wilayah memiliki andil besar dalam menentukan keberhasilan pengelolaan pembangunan wilayahnya (Mirza, 2011). Berdasarkan hal tersebut, diperlukan kajian pada Provinsi Jawa Timur yang merupakan salah satu provisi dengan jumlah penduduk tertinggi di Indonesia. Kemudian, mempertimbangkan juga kondisi IPM Jawa Timur yang ternyata masih berada diperingkat sedang dibandingkan provinsi lain di Pulau Jawa. Dengan demikian, penelitian ini bertujuan untuk menganalisis pengaruh keluhan kesehatan, pengangguran, kemiskinan dan pengeluaran pemerintah terhadap Indeks Pembangunan Manusia (IPM) di Provinsi Jawa Timur pada tahun 2015-2018.

\section{Tinjauan Pustaka \\ Indeks Pembangunan Manusia (IPM)}

Indeks Pembangunan Manusia (IPM) adalah ringkasan dari indikator tiga dimensi utama dalam pembangunan manusia yang berupa umur panjang dan hidup sehat, berpengetahuan (pendidikan) dan standar hidup yang layak (UNDP, 2019). Dasar dari pembangunan manusia yaitu dengan memposisikan manusia sebagai aset negara yang sesungguhnya dan mampu menciptakan pertumbuhan dalam bidang ekonomi, sosial, politik, budaya, dan lingkungan untuk meningkatkan taraf kehidupan masyarakat. Indeks Pembangunan Manusia (IPM) adalah indikator pembangunan kualitas dari kehidupan masyarakat dan hidup sehat, pengetahuan serta standar hidup yang layak. Dimensi umur panjang dan hidup sehat diwakili oleh indikator umur harapan hidup saat lahir. Dimensi pengetahuan diwakili oleh indikator harapan lama sekolah dan rata-rata lama sekolah. Dimensi standar hidup layak diwakili oleh pengeluaran per kapita (BPS, 2019).

\section{Keluhan Kesehatan}

Menurut laman resmi Badan Pusat Statistik (BPS) Indonesia, keluhan kesehatan merupakan keadaan dari seseorang yang mengalami gangguan kesehatan maupun 
kejiwaan, baik karena penyakit akut, penyakit kronis (meskipun selama sebulan terakhir tidak mempunyai keluhan), kecelakaan, kriminal atau hal yang lain. Kemudian, konsep keluhan kesehatan juga dibahas oleh Kementerian Kesehatan RI (2017) yang menyatakan bahwa keluhan kesehatan yaitu keadaan seseorang yang mengalami gangguan kesehatan atau kejiwaan baik dikarenakan gangguan atau penyakit yang sering dialami penduduk seperti panas, pilek, diare, pusing, sakit kepala, maupun karena penyakit akut, penyakit kronis, kecelakaan, kriminalitas atau keluhan lainnya. Keluhan kesehatan tidak selalu mengganggu kegiatan sehari-hari, karena ketika mengganggu akan menghambat upaya peningkatan kesejahteraan. Keluhan kesehatan yang mengganggu kegiatan sehari-hari ini disebut sebagai kondisi sakit yang diakibatkan oleh daya tahan tubuh yang menurun sehingga menyebabkan kondisi tubuh rentan terhadap penyakit.

Dalam penelitian ini menggunakan definisi keluhan kesehatan dan berobat jalan selama sebulan terakhir menurut Bandan Pusat Statistik. Sebagai lanjutannya, berobat jalan merupakan upaya dari anggota rumah tangga yang memiliki keluhan kesehatan untuk memeriksakan diri serta mendapatkan pengobatan dengan cara medatangi tempat-tempat pelayanan modern atau tradisional tanpa menginap. Upaya yang dilakukan termasuk juga dengan mendatangkan petugas kesehatan ke rumah anggota rumah tangga.

\section{Tingkat Pengangguran Terbuka}

Tingkat pendapatan merupakan salah satu faktor yang menentukan kemakmuran masyarakat. Pendapatan masyarakat dapat mencapai tingkat maksimum apabila penggunaan tenaga kerja penuh (full employment) dapat terwujud. Pengangguran akan mengurangi tingkat pendapatan masyarakat dan kesejahteraan hidup juga menjadi berkurang (Baeti, 2013). Menurut Sukirno (2004), pengangguran merupakan suatu kondisi seseorang yang tergolong dalam angkatan kerja yang ingin mendapatkan pekerjaan namun belum mendapatkannya. Secara umum, definsi tersebut telah sesuai dengan konsep pengangguran terbuka yang dikeluarkan oleh Badan Pusat Statistik (BPS). Konsep BPS pada pengangguran terbuka yaitu seseorang yang tidak mempunyai pekerjaan dan sedang mencari pekerjaan, tidak memiliki pekerjaan dan tidak mencari pekerjaan. Hal tersebut dikarenakan seseorang yang bersangkutan merasa tidak mungkin mendapat pekerjaan atau sudah punya pekerjaan namun belum mulai bekerja.

\section{Kemiskinan}

Badan Pusat Statistik (BPS) menggunakan konsep kemampuan pemenuhan kebutuhan dasar (basic needs approach). Dengan menggunakan pendekatan ini, maka kemiskinan dipandang sebagai ketidakmampuan dari segi ekonomi untuk memenuhi kebutuhan dasar makanan dan bukan makanan yang diukur dari segi pengeluaran. Dalam hal ini, penduduk miskin merupakan penduduk yang mempunyai rata-rata pengeluaran perkapita tiap bulan dibawah garis kemiskinan. Data jumlah penduduk miskin berasal dari data Susenas dalam Modul Konsumsi dan Pengeluaran. Seperti halnya pada kemiskinan yang dikemukakan Mustaqimah et al. (2017) bahwa kemiskinan absolut merupakan suatu keadaan dari kebutuhan minimum untuk bertahan hidup yang tidak dapat terpenuhi dengan pendapatan yang dimiliki seseorang atau suatu keluarga.

\section{Pengeluaran Pemerintah}

Setiap perencanaan dalam penganggaran atas suatu program dan kegiatan akan bermuara pada batasan anggaran. Keterbatasan anggaran tersebut mampu memunculkan beberapa urutan pilihan atau prioritas dari pentingnya belanja pemerintah yang berkualitas. Kedisiplinan yang tinggi terhadap suatu prioritas, maka akan menentukan ketepatan alokasi anggaran. Hal tersebut dapat ditunjukkan oleh indikator besar alokasi belanja. Selain itu, Mustaqimah et al. (2017) mengemukakan besarnya pengeluaran pemerintah menjadi ukuran seberapa besar perhatian dari pemerintah terhadap usaha pengembangan kualitas sumber daya manusia. Sama halnya dengan Guritno (1993) bahwa pengeluaran pemerintah merupakan suatu nilai pembelanjaan yang dilakukan oleh pemerintah setempat dan digunakan untuk kepentingan masyarakat. Pengeluaran pemerintah juga dapat mengindikasikan berlakunya kebijakan pemerintah. Dalam pelaksanaannya, apabila pemerintah telah menetapkan anggaran pembelian barang dan jasa untuk pelaksanaan suatu kebijakan maka artinya pengeluaran pemerintah dapat disebut juga biaya yang harus dikeluarkan untuk melaksanakan kebijakan yang bersangkutan.

\section{METODE}

Penelitian ini merupakan analisis data sekunder mengenai pengaruh keluhan kesehatan, pengangguran, kemiskinan dan pengeluaran pemerintah terhadap IPM di Provinsi Jawa Timur. Data yang digunakan adalah data panel yang meliputi 38 Kabupaten/Kota di seluruh wilayah Provinsi Jawa Timur dengan periode waktu empat tahun, dari tahun 2015 sampai dengan 2018. Sesuai dengan Blundell \& Matyas (1992) bahwa data panel adalah gabungan data cross-section dan data time series. Dalam penelitian ini jumlah cross sections 38 Kabupaten/Kota dan data time seriesnya dari tahun 2015-2018 di Provinsi Jawa Timur, maka menjadikan jumlah total data panel yang digunakan sebanyak 152 observasi. Variabel dependen adalah Indeks Pembangunan Manusia, variabel independen yaitu: (1) Keluhan kesehatan yang diukur dengan satuan persentase; (2) Pengangguran terbuka yang diukur dengan satuan persentase; (3) Kemiskininan yang diukur 
Nur Isnaeni Novitasari, Suharno dan Arintoko, Pengaruh Keluhan Kesehatan terhadap Indeks Pembangunan Manusia di Provinsi Jawa Timur

dengan satuan persentase; dan (4) Pengeluran pemerintah yang diukur dengan satuan rupiah. Secara ekonometrika hubungan antara keluhan kesehatan, pengangguran, kemiskinan dan pengeluaran pemerintah terhadap indeks pembangunan manusia di Provinsi Jawa Timur menggunakan persamaan sebagai berikut:

$\mathrm{IPM}_{\mathrm{it}}=\beta_{0}+\beta_{1} \mathrm{KKES}_{\mathrm{it}}+\beta_{2} \mathrm{PGG}_{\mathrm{it}}+\beta_{3} \mathrm{KMSK}_{\mathrm{it}}+\beta_{4} \mathrm{LOG}(\mathrm{BLNJA})_{\mathrm{it}}+\mathrm{E}_{\mathrm{it}}$

Keterangan:

$\begin{array}{ll}\text { IPM } & \text { : Indeks Pembangunan Manusia } \\ \text { KKES } & \text { : Keluhan Kesehatan } \\ \text { PGG } & \text { : Pengangguran Terbuka } \\ \text { KMSK } & \text { : Jumlah Penduduk Miskin } \\ \text { LOG(BLNJA) } & : \text { Pengeluaran Pemerintah } \\ \text { E } & : \text { Komponen error } \\ \mathrm{i} & : \text { Cross Section } \\ \mathrm{t} & : \text { Time series }\end{array}$

Dalam penelitian regresi liner berganda data panel terdapat 3 model ragresi yaitu Common Effect, Fixed
Effect dan Random Effect. Dalam menentukan model regresi yang terbaik maka dapat dilakukan dengan menggunakan uji kecocokan model yaitu uji Chow, Hausman, dan Lagrange Multiplier. Selain itu, model regresi yang baik adalah yang harus lolos oleh uji asumsi klasik yang meliputi uji normalitas, heteroskedastisitas, multikolinearitas dan autokorelasi (Gujarati dan Porter, 2010).

\section{HASIL DAN PEMBAHASAN \\ Hasil Analisis Regresi}

Berdasarkan output regresi linier berganda data panel Common Effect, Fixed Effect dan Random Effect. Berdasarkan uji kecocokan model didapatkan model yang terbaik adalah fixed effect model. Selain itu, fixed effect model sudah dinyatakan lolos uji asumsi klasik yang meliputi uji normalitas, heteroskedastisitas, multikolinearitas dan autokorelasi. Berikut Tabel 1 yang menunjukkan output regresi.

Tabel 1. Output Regresi Panel Model Common Effect, Fixed Effect dan Random Effect

\begin{tabular}{|c|c|c|c|c|c|}
\hline No & Variabel & Notasi & Common Effect & Fixed Effect & Random Effect \\
\hline 1 & Konstanta & $\beta_{0}$ & $\begin{array}{r}-65,6984 \\
0,0039 \\
\end{array}$ & $\begin{array}{r}41,4748 \\
0,0015 \\
\end{array}$ & $\begin{array}{r}21,8295 \\
0,0612 \\
\end{array}$ \\
\hline 2 & Keluhan Kesehatan & KKES & $\begin{array}{r}-0,0226 \\
0,4920 \\
\end{array}$ & $\begin{array}{r}-0,0426 \\
0,0000^{* * *}\end{array}$ & $\begin{array}{r}-0,0445 \\
0,0000^{* * * *}\end{array}$ \\
\hline 3 & Pengangguran & PGG & $\begin{array}{r}1,1833 \\
0,0000^{* * * *}\end{array}$ & $\begin{array}{r}-0,2124 \\
0,0000^{* * *}\end{array}$ & $\begin{array}{r}-0,1971 \\
0,0000^{* * * *}\end{array}$ \\
\hline 4 & Kemiskinan & KMSK & $\begin{array}{r}-0,0642 \\
0,0000^{* * * *} \\
\end{array}$ & $\begin{array}{r}-0,0069 \\
0,0000^{* * *} \\
\end{array}$ & $\begin{array}{r}-0,0618 \\
0,0000^{* * * *}\end{array}$ \\
\hline 5 & Pengeluaran Pemerintah & LOG(BLNJA) & $\begin{array}{r}4,9502 \\
0,0000^{* * * *}\end{array}$ & $\begin{array}{r}1,4168 \\
0,0020^{* * * *}\end{array}$ & $\begin{array}{r}2,0828 \\
0,0000^{* * * *}\end{array}$ \\
\hline \multicolumn{3}{|c|}{$R$-squared } & 0,6517 & 0,9958 & 0,6963 \\
\hline \multicolumn{3}{|c|}{ Adjusted R-squared } & 0,6421 & 0,9943 & 0,6879 \\
\hline \multicolumn{3}{|c|}{ F-statistik } & $\begin{array}{r}67,8335 \\
0,0000 \\
\end{array}$ & $\begin{array}{r}63,2256 \\
0,0000 \\
\end{array}$ & $\begin{array}{r}83,1383 \\
0,0000 \\
\end{array}$ \\
\hline
\end{tabular}

Keterangan : *** signifikan pada alfa 1 persen.

Sumber: Analisis Data Sekunder, 2020

Keluhan kesehatan berpengaruh negatif dan signifikan terhadap Indeks Pembangunan Manusia di Provinsi Jawa Timur Tahun 2015-2018 pada alpha 1 persen. Hal tersebut menunjukkan bahwa semakin tinggi tingkat keluhan kesehatan akan berdampak pada menurunnya indeks pembangunan manusia. Hasil penelitian dengan menggunakan kurun waktu tahun 2015-2018 ini ternyata masih selaras dengan penelitian BPS (2008) yang menunjukkan bahwa meningkatnya keluhan kesehatan dan angka kesakitan di suatu provinsi dapat menyebabkan IPM di daerah tersebut menurun.

Penjelasan lebih lanjut dinyatakan oleh Schultz (2010) bahwa selama 50 tahun terakhir kesehatan dapat diukur dengan angka harapan hidup. Korelasinya dengan IPM yaitu ketika angka keluhan kesehatan meningkat, maka akan mengurangi angka harapan hidup seseorang. Dengan demikian, kondisi IPM disuatu wilayah dapat menjadi lebih rendah. Berdasarkan hasil perhitungan, ditemukan bahwa keluhan kesehatan berpengaruh terhadap IPM di Provinsi Jawa Timur. Akan tetapi, sebenarnya tingkat keluhan kesehatan di Jawa Timur sebesar $51,7075 \%$ atau masih berada dibawah rata-rata nasional sebesar 51,8175\% selama kurun waktu 20152018, hal tersebut dapat dilihat pada Gambar 2.

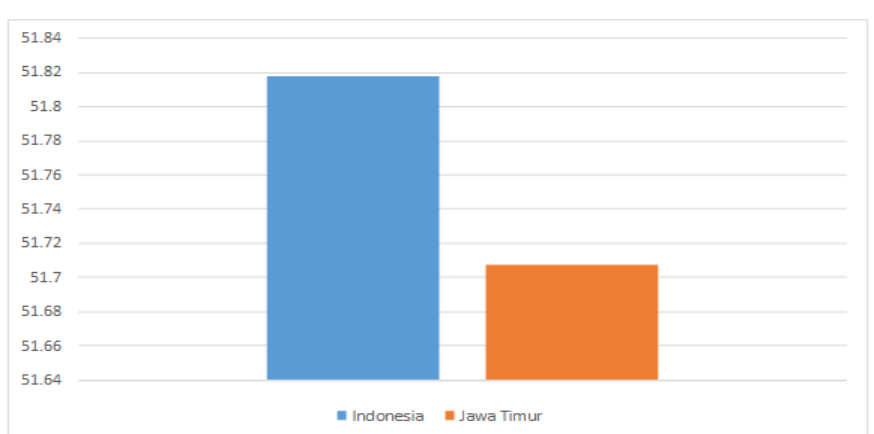

Gambar 2. Rata-Rata Persentase Penduduk yang Mempunyai Keluhan Kesehatan dan Berobat Jalan di Indonesia dan Jawa Timur Tahun 2015-2018

Sumber: Badan Pusat Statistik, 2019, 2016 (Data Diolah) 
Data yang digunakan adalah keluhan kesehatan dan berobat jalan, artinya data berasal dari anggota rumah tangga yang mengalami keluhan kesehatan dan memiliki upaya untuk mendatangi tempat-tempat pelayanan kesehatan. Jadi, meskipun keluhan kesehatan berpengaruh negatif pada indeks pembangunan manusia di Jawa Timur. Keberadaan angka persentasenya juga tergantung pada ketersediaan fasilitas kesehatan. Berdasarkan data terakhir pada tahun 2018 dari Badan Pusat Statistik dan Dinas Kesehatan terdapat 380 Rumah Sakit, 964 Puskesmas, 46.733 Posyandu dan 4.413 Polindes dan angkanya memiliki kenaikan dari tahun 2016-2018. Pada penelitian Serna et al. (2019) telah membuktikan bahwa negara-negara yang maju dengan indeks pembangunan manusia tinggi dapat mengontrol prevalensi dari penyakit kanker mulut berkat pelayanan kesehatan yang dimilikinya beserta kebijakan preventif dari pemerintah. Hal tersebut menjelaskan, keberadaan keluhan kesehatan yang berpengaruh negatif terhadap indeks pembangunan manusia di Jawa Timur dapat terkendali, selama daerah tersebut memiliki fasilitas pelayanan kesehatan yang memadai beserta kebijakan preventif dari pemerintah daerah.

Pengangguran berpengaruh negatif dan signifikan terhadap Indeks Pembangunan Manusia di Provinsi Jawa Timur Tahun 2015-2018 pada alpha 1 persen. Hal tersebut menunjukkan bahwa semakin tinggi angka pengangguran akan berdampak pada menurunnya indeks pembangunan manusia. Menurut Baeti (2013) pengangguran akan mengurangi pendapatan masyarakat dan hal ini akan mengurangi tingkat kesejahteraan yang mereka capai. Hal tersebut disebabkan pendapatan yang diterima oleh masyarakat akan digunakan dalam memenuhi kenbutuhan sehari-hari seperti sandang pangan, dan papan. Apabila tidak memiliki pendapatan maka masyarakat akan mengkonsumsi makanan yang kurang bergizi dan nantinya akan berdampak pada kualitas kesehatan. Apabila pemenuhan gizi yang tidak memadai atau dapat dikatakan kekurangan gizi maka secara nasional akan berdampak pada penurunan indeks pembangunan manusia, karena pada dasarnya komponen pembentuk indeks pembangunan manusia terdiri dari kesehatan, kemampuan daya beli, dan pendidikan. Sesuai dengan penelitian Yuliani \& Saragih (2014) bahwa angka pengangguran memiliki pengaruh negatif terhadap indeks pembangunan manusia di Provinsi Jawa Tengah atau artinya ketika jumlah pengangguran di Provinsi Jawa Tengah meningkat maka indeks pembangunan manusia disana akan menurun begitu pula sebaliknya. Memperkuat pernyataan tersebut, pada penelitian Sofilda et al. (2015) telah menghitung variabel determinan dari indeks pembangunan manusia seluruh provinsi di Indonesia periode 2004-2013 mendapati pengangguran berpengaruh negatif terhadap indeks pembangunan manusia.
Kemiskinan berpengaruh negatif dan signifikan terhadap Indeks Pembangunan Manusia di Provinsi Jawa Timur Tahun 2015-2018 pada alpha 1 persen. Hal tersebut menunjukkan bahwa semakin tinggi angka kemiskinan akan berdampak pada menurunnya indeks pembangunan manusia. Hasil penelitian ini sesuai dengan teori kemiskinan absolut dimana sejumlah penduduk yang tidak mampu mendapatkan sumber daya yang cukup untuk memenuhi kebutuhan dasar, penduduk hidup di bawah pendapatan rill minimum atau dapat dikatakan hidup dibawah kemiskinan (Todaro \& Smith, 2006). Pendapatan merupakan sumber utama masyarakat yang digunakan dalam peningkatan kualitas hidup atau kesejahteraan. Apabila jumlah penduduk miskin semakin meningkat dan tidak adanya subsidi pangan dari pemerintah maka dapat berdampak terhadap penurunan indeks pembangunan manusia dari skala regional maupun nasional. Hasil penelitian ini sesuai dengan Mirza (2011) yang menunjukkan kemiskinan berpengaruh negative terhadap indeks pembangunan manusia di Provinsi Jawa Tengah.

Pengeluaran pemerintah berpengaruh positif dan signifikan terhadap Indeks Pembangunan Manusia di Provinsi Jawa Timur Tahun 2015-2018 pada alpha 1 persen. Hal tersebut menunjukkan bahwa semakin tinggi pengeluaran pemerintah bidang kesehatan akan berdampak pada meningkatnya indeks pembangunan manusia. Beberapa penelitian terdahulu juga menunjukkan hal yang sama yaitu baik pengeluaran pemerintah maupun belanja modal berpengaruh positif terhadap indeks pembangaun manusia (Yuliani \& Saragih, 2014), (Mirza, 2011). Hal tersebut dikarenakan pengeluaran pemerintah merupakan instrument utama dalam mengendalikan kualitas sumber daya manusia melalui bidang pendidikan dan kesehatan serta subsidi pangan pada penduduk miskin. Apabila manfaat pengeluaran pemerintah dapat dirasakan langsung oleh masyarakat maka indeks pembangunan manusia juga akan meningkat. Hal tersebut didasarkan pada layanan pendidikan dan kesehatan yang dapat dijangkau oleh semua elemen masyarakat serta didukung oleh bantuan pangan. Menurut Mustaqimah et al. (2017) pengeluaran pemerintah menjadi ukuran seberapa besar perhatian pemerintah pada usaha pengembangan kualitas sumber daya manusia. Implikasinya dengan penelitian ini artinya, ketika Pemerintah Daerah Provinsi Jawa Timur ingin menaikan indeks pembangaun manusia maka diperlukan perencaan anggaran pengeluaran daerah yang direalisasikan melalui program-program tepat sasaran.

\section{SIMPULAN}

Investasi dalam modal manusia memiliki peran penting untuk meningkatkan ekonomi suatu negara. Provinsi Jawa Timur menjadi salah satu provinsi dengan jumlah penduduk terpadat di negara Indonesia sehingga keadaan sumber daya manusia pada provinsi tersebut 
Nur Isnaeni Novitasari, Suharno dan Arintoko, Pengaruh Keluhan Kesehatan terhadap Indeks Pembangunan Manusia di Provinsi Jawa Timur

memiliki pengaruh yang besar terhadap pembangunan nasional di Indonesia. Hasil penelitian menemukan bahwa keluhan kesehatan, pengangguran dan kemiskinan berpengaruh negatif dan signifikan terhadap indeks pembangunan manusia di Provinsi Jawa Timur tahun 2015-2018. Sementara itu, pengeluaran pemerintah berpengaruh positif dan signifikan terhadap indeks pembangunan manusia di Provinsi Jawa Timur 2015-2018. Berdasarkan hasil penelitian maka rekomendasi kebijakan yang dapat diusulkan yaitu: (1) Perlunya peningkatan infrastruktur kesehatan dan pengeluaran pemerintah di bidang kesehatan; dan (2) Perlunya peningkatan kesempatan kerja agar kemiskinan dan pengangguran berkurang.

\section{DAFTAR PUSTAKA}

Arisman. (2018). Determinant of Human Development Index in ASEAN Countries. SIgnifikan: Jurnal Ilmu Ekonomi Vol.7 No.1, 113-122.

Badan Pusat Statistik. (2009). Indeks Pembangunan Manusia 2007-2008. Jakarta: Badan Pusat Statistik.

Baeti, N. (2013). Pengaruh Pengangguran, Pertumbuhan Ekonomi dan Pengeluaran Pemerintah Terhadap Pembangunan Manusia Kabupaten/Kota Di Provinsi Jawa Tengah Tahun 2007-2011. Economics Development Analysis Journal, 85-97.

Bleakley, H. (2010). Health, Human Capital, and Development. Annual Review of Economics, 283310.

Blundell, R., \& Matyas, L. (1992). Panel Data Analysis: An Introductory Overview. Structural Cange and Economic Dynamics Vol.3 No.2, 291-299.

BPS. (2016). Profil Statistik Kesehatan 2016. Jakarta: BPS.

BPS. (2019). Indeks Pembangunan Manusia 2018. Jakarta: Badan Pusat Statistik Republik Indonesia.

BPS. (2019). Profil Statistik Kesehatan 2019. Jakarta: BPS.

BPS. (2021). Indeks Pembangunan Manusia Menurut Provinsi (Metode Baru), 2010-2019. Retrieved from Badan Pusat Statistik: https://www.bps.go.id/dynamictable/2020/02/18/1 772/indeks-pembangunan-manusia-menurutprovinsi-metode-baru-2010-2019.html

Dinas Kesehatan Provinsi Jawa Timur. (2019). Profil Kesehatan Provinsi Jawa Timur Tahun 2018. Surabaya: Kementerian Kesehatan Republik Indonesia.

Elistia, \& Syahzuni, B. (2018). The Correlation of The Human Development Index (HDI) Towards Economic Growth (GDP Per Capita) In 10 Asean Member Countries. Journal of Humanities and Social Studies, 40-46.

Guritno, M. (1993). Ekonomi Publik. Yogyakarta: BPFE.
Gujarati, D.N. \& Porter, D.C. (2010). Dasar-Dasar Ekonometrika, Edisi 5. Jakarta: Salemba Empat

Hartanto, W., Islami, N., Mardiyana, L., Ikhsan, F., \& Rizal, A. (2019). Analysis of Human Development Index In East Java Province Indonesia. IOP Conference Series: Earth and Environmental Science, 1-7.

Hendarmin, \& Kartika, M. (2019). The Relationship Between Human Capital and the Regional Economy Productivity. Journal of Economics and Policy, 138-152.

Kementerian Kesehatan RI. (2017). Analisis Lansia Di Indonesia. Jakarta: Kementerian Kesehatan Republik Indonesia.

Mirza, D. (2011). Pengaruh Kemiskinan, Pertumbuhan Ekonomi, dan Belanja Modal Terhadap IPM Jawa Tengah. Jurnal Ekonomi dan Kebijakan Vol.4 No.2, 102-113.

Mustaqimah, K., Hartoyo, S., \& Fahmi, I. (2017). Peran Belanja Mdal Pemerintah dan Investasi Pembangunan Manusia Dalam Mengurangi Tingkat Kemiskinan di Indonesia. Jurnal Ekonomi dan Kebijakan Pembangunan Vol.6 No.2, 1-15.

Schultz, T. (2010). Health Human Capital and Economic Development. Journal of African Economies Vol.19 No.3, 12-80.

Serna, B., Carrillo, E., Rizo, V., Amaral, R., \& Eguia, R. (2019). Relationship Between The Human Development Index and Its Components with Oral Cancer In Latin America. Journal of Epidemiology and Global Health, 223-232.

Sofilda, E., Hermiyanti, P., \& Hamzah, M. (2015). Determinant Variable Analysis of Human Development Index in Indonesia (Case For High And Low Index at Period 2004-2013). IODAnternational Journal of Sustainable Development Vol. 8 No.9, 11-27.

Subdirektorat Statistik Kesehatan dan Perumahan. (2019). Profil Statistik Kesehatan 2019. Jakarta: Badan Pusat Statistik.

Sukirno, S. (2004). Pengantar Teori Makroekonomi. Jakarta: PT Raja Grafindo Persada.

Todaro. M. P. \& Smith. S. C. (2006). Pembangunan Ekonomi. Edisi ke 9. Jakarta: Erlangga.

UNDP. (1990). Human Development Report 1990. New York: Oxford University Press.

UNDP. (2019). Human Development Report 2019: Beyond income, beyond averages, beyond today: Inequalities in human development in the 21 st century. New York: United Nations Development Programme.

Yuliani, T., \& Saragih, N. (2014). Determinan Pembangunan Manusia Di Kabupaten/Kota Provinsi Jawa Tengah. Journal of Economics and Policy Vol. 7 No.1, 60-72. 